\title{
Pendekatan Problem Posing Terhadap Kemampuan Berpikir Matematis Siswa SMP
}

\section{S. Setiyani}

Program Studi Pendidikan Matematika, Universitas Swadaya Gunung Jati, Cirebon, Indonesia; setiyani 0401509081@yahoo.com

Info Artikel: Dikirim: 25 Juli 2019; Direvisi: 25 Agustus 2019; Diterima: 2 September 2019 Cara sitasi: Setiyani, S. (2020). Pendekatan Problem Posing Terhadap Kemampuan Berpikir Matematis Siswa SMP. JNPM (Jurnal Nasional Pendidikan Matematika), 4(1), 1-12.

Abstrak. Penelitian ini bertujuan untuk mengetahui pengaruh pendekatan problem posing terhadap kemampuan berpikir matematis siswa. Adapun kemampuan berpikir matematis siswa yang diteliti adalah kemampuan berpikir kreatif dan kemampuan mengajukan pertanyaan. Penelitian ini merupakan penelitian eksperimen semu, dengan desain pretest-postest control group design. Populasi penelitian ini adalah siswa kelas VII dari sebuah Sekolah Menengah Pertama (SMP) di kota Cirebon. Sampel penelitian terdiri dari dua kelas yaitu kelas eksperimen dan kontrol. Instrumen yang digunakan meliputi lembar wawancara, lembar observasi, tes kemampuan berpikir kreatif matematis dan tes kemampuan mengajukan pertanyaan matematis. Analisis data menggunakan uji regresi linier sederhana dan uji koefisien determinasi dengan data diasumsikan normal dan homogen. Berdasarkan hasil penelitian, diketahui bahwa terdapat pengaruh pendekatan problem posing terhadap kemampuan berpikir matematis siswa. Pendekatan problem posing memberikan pengaruh yang lebih besar terhadap kemampuan berpikir kreatif daripada kemampuan mengajukan pertanyaan. Melalui pendekatan problem posing, siswa akan semakin terbiasa mengajukan pertanyaan dan berpikir kreatif dalam menyelesaikan masalah.

Kata Kunci: Kemampuan Berpikir Kreatif Matematis, Kemampuan Mengajukan Masalah Matematis, Pendekatan Problem Posing.

Abstract. This research aimed to determine the effect of the problem posing approach to students' mathematical abilities. The mathematical abilities of the students that studied were the ability to think creatively and ask questions. This research was a quasi-experimental study with the pretest-posttest control group design. The statistical test used was a simple regression test analysis and t-test. The population of this study was $7^{\text {th }}$ grade students from one of the junior high schools in Cirebon. The research sample was two classes as the experimental class and control class. The 
instruments used included interview sheets, observation sheets, tests of mathematical creative thinking skills, and tests of ability to ask questions. Based on the results of the study, it was known that there was an effect of the problem posing approach to students' mathematical abilities. The problem posing approach had given a greater influence on the ability to think creatively than the ability to ask questions. The mathematical abilities of students from those who applied the problem posing approach were better than the scientific approach. Through the problem posing approach, students would increasingly be accustomed to asking questions and thinking creatively in solving problems.

Keywords: Mathematical Creative Thinking Ability, Mathematical Problem Posing, Problem Posing Approach.

\section{Pendahuluan}

Pelajaran matematika di SMP memegang peran penting dalam perkembangan kemampuan matematis siswa pada jenjang selanjutnya. Kurangnya penguasaan konsep dasar matematika yang sudah diberikan sejak SD dan SMP akan menyebabkan kesulitan belajar dalam mempelajari matematika di sekolah menengah (Hartati, 2016). Mengingat perkembangan intelektual siswa SMP yang secara umum masih berada pada tahap peralihan, maka dalam membangun pengetahuan matematika seharusnya berangkat dari hal yang nyata ke abstrak (Saragih, 2011). Oleh karena itu pada masa peralihan ini diperlukan usaha tertentu untuk mempelajari dan menguasai matematika dalam segala bentuk kegiatan belajar. Usaha yang dapat dilakukan untuk meningkatkan kemampuan matematis siswa adalah dengan menciptakan ruang kelas aktif, memfasilitasi kegiatan diskusi, mengajukan pertanyaan dan memecahkan masalah yang menantang secara kognitif (Knott, 2010).

Beberapa kemampuan matematis diantaranya pemahaman, pemecahan masalah, komunikasi, koneksi, penalaran, berpikir logis, berpikir kritis, dan berpikir kreatif matematis (Hendriana, Rohaeti, \& Sumarmo, 2017). Kemampuan matematis tersebut dapat ditumbuhkembangkan melalui pembelajaran yang bermakna. Salah satu kemampuan berpikir matematis yang perlu dikembangkan sejak dini adalah kemampuan berpikir kreatif (Ulfah, Prabawanto, \& Jupri, 2017). Siswa yang memiliki kemampuan berpikir kreatif akan mampu bertahan dimana kompleksitas masalah pada era persaingan global ini semakin tinggi (Wasiran \& Andinasari, 2019). Hal ini sejalan dengan tujuan pembelajaran matematika pada kurikulum 2013 antara lain melatih berpikir logis, sistematis, kritis, kreatif, dan cermat serta berpikir objektif dan terbuka untuk menghadapi masalah dalam kehidupan sehari-hari serta untuk menghadapi masa depan yang selalu berubah 
(Hendriana, Rohaeti, \& Sumarmo, 2017). Berdasarkan tuntutan kurikulum tersebut, maka siswa perlu memiliki kemampuan berpikir tingkat tinggi misalnya kemampuan berpikir kreatif dan mengajukan masalah matematis. Tingkatan berpikir sederhana hanya bermanfaat untuk menjawab soal ulangan yang belum tentu dapat dipergunakan dalam kehidupan nyata setelah sekolah (Herianingtyas \& Harmawati, 2017). Menurut Jay dan Perkins (Yuan, 2009), tindakan menemukan dan merumuskan masalah adalah salah satu kunci dari pemikiran kreatif dan tindakan kreatif dalam berbagai hal

Para ahli telah mendefinisikan berpikir kreatif dari sudut pandang yang berbeda. Berpikir kreatif adalah sebuah kebiasaan dari pikiran yang dilatih dengan memperhatikan intuisi, menghidupkan imajinasi, mengungkapkan kemungkinan-kemungkinan baru, membuka sudut pandang yang menakjubkan, dan membangkitkan ide-ide yang tidak terduga (Johnson, 2010). Dengan kata lain, seorang yang kreatif dapat menghasilkan ide-ide baru, menganalisis ide-ide ini, dan menjual ide-ide itu kepada orang lain (Sternberg, 2006) Kreativitas merupakan suatu proses atau hasil dari kemampuan seseorang dalam mengembangkan ide-ide baru untuk memecahkan suatu masalah (Antonio, Lanawati, Wiriana, \& Christina, 2014). Balka (Mann, 2005) mendefinisikan kemampuan berpikir kreatif matematik meliputi kemampuan berpikir konvergen dan divergen yang ditandai dengan kemampuan menentukan pola yang ada dalam situasi masalah, merumuskan/memformulasikan hipotesis matematika, mengajukan solusi dan ide-ide baru yang tidak biasa, mengidentifikasi informasi matematis yang hilang dari masalah yang diberikan, dan merinci masalah matematis yang umum ke dalam sub-sub masalah yang lebih spesifik. Torrance melihat bahwa kemampuan berpikir kreatif ditandai dengan empat aspek yaitu: fluency, flexibility, originality dan elaboration (Torrance, 1972).

Pengajuan masalah merupakan salah satu kemampuan untuk mengidentifikasi kreativitas seseorang karena erat hubungannya antara kemampuan berpikir kreatif dengan kemampuan mengajukan masalah. Sebagai contoh, memandang kemampuan siswa untuk mengajukan pertanyaan matematika berdasarkan skenario yang diberikan sebagai salah satu tolak ukur kreativitas matematika (Yuan \& Sriraman, 2011). Pengembangkan tes mengukur kreativitas matematis, dimana siswa mengajukan masalah matematika yang dapat dijawab dengan informasi yang disediakan dalam soal cerita tentang situasi dunia nyata. Sama hal nya dengan penelitian yang dilakukan Balka (Silver, 1994), meminta subyek untuk mengajukan masalah matematika dengan memperhatikan tiga aspek: 
kelancaran, fleksibilitas, dan orisinalitas Penelitian serupa dilakukan pula oleh Siswono yang telah menggambarkan karakteristik tingkat berpikir kreatif siswa SMP melalui 5 level yaitu level 0, 1, 2, 3, 4. Pembedaan level didasarkan pada kelancaran, fleksibilitas, dan kebaruan dalam pemecahan masalah dan pengajuan masalah matematis (Siswono, 2010).

Siswa yang memiliki imajinasi kreatif akan menemukan konsep baru, berawal dari mengajukan pertanyaan, melihat beberapa kemungkinan, dan memandang suatu masalah dari sudut pandang yang berbeda. Oleh karena itu kemampuan mengajukan masalah merupakan aspek penting dalam pengembangan matematika maupun ilmu-ilmu lainnya (Mahmudi, 2007). Situasi problem posing diklasifikasikan menjadi 3 bagian yaitu sebagai situasi bebas, semi-terstruktur dan terstruktur (Stoyanova \& Ellerton, 1996). Menurut klasifikasi ini, situasi bebas apabila siswa diberi kebebasan untuk membuat pertanyaan. Situasi semi terstruktur ketika siswa diminta membuat pertanyaan dengan cara mengaitkan informasi dengan pengetahuan yang sudah dimiliki. Sedangkan situasi terstruktur terjadi apabila siswa dapat membuat soal baru dari soal yang telah diselesaikan. Kemampuan mengajukan pertanyaan pada penelitian ini diterapkan pada situasi bebas dan semi terstruktur. Adapun indikator kemampuan pengajuan masalah dalam penelitian ini meliputi; reformulasi, rekonstruksi dan imitasi (Anwar \& Sofiyan, 2018).

Setiap siswa memiliki potensi kreatif dan kemampuan mengajukan masalah yang dapat dikembangkan di dalam kelas. Namun, fokus perhatian pada upaya meningkatkan kemampuan berpikir kreatif dan menumbuhkembangkan kemampuan mengajukan pertanyan matematis masih belum optimal dilakukan. Kemampuan berpikir kreatif matematis siswa di tingkat SMP pun masih sangat rendah, hal ini karena ketika siswa diberikan siswa tidak mau mengerjakan soal bahkan siswa menyerah terlebih dahulu sebelum mencoba menyelesaikan masalah (Hendriana \& Fadhillah, 2019). Berdasarkan hasil wawancara di salah satu SMPN Kota Cirebon, guru memaparkan bahwa siswa masih cenderung mengikuti langkah-langkah penyelesaian soal yang dicontohkan oleh guru ataupun melihat dari buku teks dan masih belum berani dalam bertanya. Tradisi pembelajaran seperti ini merupakan karakteristik umum dan banyak terjadi di sekolah-sekolah dimana guru biasanya menjelaskan konsep secara informatif, memberikan contoh soal, dan latihan-latihan soal. Prestasi belajar siswa menjadi fokus pembelajaran matematika sehingga kreativitas dan kemampuan mengajukan pertanyaan kurang berkembang maksimal. Oleh karena itu, pemilihan pendekatan dan model pembelajaran hendaknya dapat 
mengatasi berbagai masalah yang dialami siswa. Salah satu pendekatan pembelajaran yang diduga sesuai dengan tuntutan dan menjadi solusi permasalahan yang ada adalah pendekatan problem posing.

Problem posing diartikan sebagai pengajuan masalah, adalah pendekatan pembelajaran yang menekankan pada siswa untuk membentuk/mengajukan soal berdasarkan informasi atau situasi yang diberikan, informasi yang ada diolah dalam pikiran dan setelah dipahami maka siswa akan bisa mengajukan pertanyaan (Herawati, Siroj, \& Basir, 2010). Proses pengajuan masalah berdasarkan ide kreatif masing-masing siswa. Lebih lanjut pendekatan problem posing dapat mengembangkan kreativitas pada anak sekolah (Ayllon, Gomez, \& Ballesta-Claver, 2016). Penggunaan problem posing dalam kurikulum matematika sangat dianjurkan oleh Silver (1994), yang mengatakan bahwa problem posing merupakan salah satu pendekatan pembelajaran yang penting dalam kurikulum matematika.

Problem posing merupakan inti penting dalam disiplin ilmu matematika dan dalam hakikat berpikir matematis. Hal ini dikarenakan di dalam problem posing terdapat inti dari aktivitas matematika, termasuk aktivitas dimana siswa membangun masalahnya sendiri dan menyelesaikannya (Mahmuzah, 2015). Oleh sebab itu tujuan dari penelitian ini adalah ingin mengetahui terdapat pengaruh penerapkan pendekatan problem posing terhadap kemampuan berpikir matematis.

\section{Metode}

Metode penelitian yang peneliti gunakan yaitu metode eksperimen semu. Dalam penelitian ini peneliti menggunakan dua kelas sebagai kelas kontrol dan kelas eksperimen. Dimana kelas kontrol diberikan pendekatan saintifik, dan kelas eksperimen diberikan pendekatan problem posing. Desain penelitian yang digunakan dalam penelitian ini adalah pretest-postest control group design. Desain penelitiannya, dapat divisualisasikan pada Gambar 1.

\begin{tabular}{|ccccc|}
\hline & Kelas & Pretes & Perlakuan & Pascates \\
Acak & $\mathrm{A}$ & $\longrightarrow \mathrm{O}_{1} \longrightarrow \mathrm{O}_{2}$ \\
Acak & $\mathrm{B}$ & $\longrightarrow \mathrm{O}_{1} \longrightarrow \mathrm{O}_{2}$ \\
\hline
\end{tabular}

Gambar 1. Desain Penelitian

Keterangan :

A: kelas eksperimen

B: kelas kontrol

X: perlakuan dengan menggunakan pendekatan problem posing. 
O1: prates (awal tes)

$\mathrm{O}_{2}$ : pascates (tes akhir)

Populasi dalam penelitian ini adalah siswa kelas VII di salah satu SMP Negeri Kota Cirebon, sedangkan sampel yang dipilih terdiri dari dua kelas yaitu kelas sebagai kelas eksperimen dengan dan kelas sebagai kelas kontrol. Data yang dikumpulkan pada penelitian ini berupa data kemampuan berpikir kreatif matematis, kemampuan mengajukan pertanyaan, dan aktivitas siswa pada kelas eksperimen. Data yang telah dikumpulkan diolah menggunakan uji statistik dengan bantuan software SPSS.

\section{Hasil dan Pembahasan}

Data kemampuan mengajukan masalah di kelas eksperimen dan kontrol didapatkan melalui postes kemampuan mengajukan masalah. Tabel 1 merupakan perolehan data nilai posttes kemampuan mengajukan masalah.

\begin{tabular}{lll}
\multirow{2}{*}{ Tabel 1. Kemampuan Mengajukan Masalah Matematis } \\
\cline { 2 - 3 } Data Statistik & \multicolumn{2}{c}{ MPP } \\
\cline { 2 - 3 } & Eksperimen & Kontrol \\
\hline Jumlah & 56 & 30 \\
Nilai Tertinggi & 15 & 47 \\
Nilai Terendah & 35,19 & 4 \\
Rata-rata & 13,94 & 26,58 \\
Simpangan Baku & 13,01 \\
\hline
\end{tabular}

Tabel 1 menunjukan bahwa nilai rata-rata posttest kemampuan mengajukan masalah di kelas eksperimen termasuk kecil karena jauh dari skor maksimal yaitu 100, begitu pula dengan rata-rata posttest kelas kontrol. Walaupun nilai rata-rata kelas kontrol lebih kecil dari kelas eksperimen, namun simpangan bakunya lebih kecil. Artinya siswa pada kelas kontrol lebih homogen daripada kelas eksperimen. Dari data yang telah diperoleh kemudian dianalisis, untuk melihat adanya pengaruh model problem posing terhadap kemampuan mengajukan masalah matematis siswa.

Pengaruh aktivitas siswa pada model problem posing terhadap kemampuan mengajukan masalah matematis siswa diketahui dengan melakukan pengujian analisis yaitu uji regresi linier sederhana ditunjukan pada Tabel 2. Tabel 2 menunjukan bahwa nilai Sig. sebesar 0.223, nilai tersebut lebih besar daripada nilai $\alpha=0.05$. Karena nilai Asymp. Sig (2-tailed) $>\alpha$, maka $\mathrm{H}_{0}$ diterima dan $\mathrm{H}_{1}$ ditolak. Sehingga, dapat disimpulkan bahwa aktivitas siswa 
yang menggunakan model problem posing tidak berpengaruh terhadap nilai posttest kemampuan mengajukan masalah matematis siswa.

Tabel 2. Hasil Uji Regresi Linier Sederhana

\begin{tabular}{lllllll}
\hline Model & & Sum of Squares & df & Mean Square & F & Sig. \\
\hline 1 & Regression & 296.589 & 1 & 296.589 & 1.559 & $.223^{\mathrm{a}}$ \\
& Residual & 4757.486 & 25 & 190.299 & & \\
& Total & 5054.074 & 26 & & & \\
\hline
\end{tabular}

a. Predictors: (Constant), Student_Activity

b. Dependent Variable: MPP_Exp

Hal tersebut dikarenakan dalam pembelajaran model problem posing siswa belum terbiasa dapat mengajukan masalah dan mencari solusinya sendiri, kemudian mencari solusi dari soal yang diajukan oleh siswa lainnya. Banyak siswa mengalami kesulitan untuk bertanya dan lebih senang menunggu untuk menjawab pertanyaan daripada mempertanyakan sesuatu (Royani \& Muslim, 2014). Hasil ini pula sejalan dengan penelitian terdahulu bahwa pembelajaran problem posing memberikan pengaruh yang signifikan pada siswa dalam kelompok tinggi dibandingkan dengan kelompok sedang dan rendah (Herawati, Siroj, \& Basir, 2010). Pada aktivitas problem posing, siswa harus dapat mengaitkan informasi yang telah diperoleh dengan materi yang sudah dipelajari, menyelesaikan soal secara sistematis, dan membuat soal yang sejenis dengan soal yang diberikan. Aktivitas-aktivitas tersebut dapat dilakukan dengan baik oleh siswa yang memiliki High Order Thinking Skill (HOTS). Sama hal nya dengan siswa yang menggunakan model pembelajaran konvensional, saat diberikan tugas untuk mengajukan masalah mereka bingung dengan apa yang akan mereka pertanyakan padahal telah diberikan informasi untuk mengajukan masalahnya, dalam pembelajaran konvensional siswa hanya dituntut untuk dapat mencari solusi dari suatu permasalahan dan lebih berpikir divergen.

Selanjutnya terkait kemampuan berpikir kreatif, hasil posttest kemampuan berpikir kreatif matematis ditunjukan pada Tabel 3.

\begin{tabular}{cll} 
Tabel 3. Kemampuan Berpikir Kreatif Matematis (CMT) \\
\cline { 2 - 3 } Data Statistik & \multicolumn{2}{c}{ CMT } \\
\cline { 2 - 3 } & Eksperimen & Kontrol \\
\hline Jumlah & 66,67 & 30 \\
Nilai Tertinggi & 81,67 \\
Nilai Terendah & 8,33 & 8,33 \\
Rata-rata & 48,15 & 27,77 \\
Simpangan Baku & 18,39 & 13,01 \\
\hline
\end{tabular}


Nilai rata-rata posttest kemampuan berpikir kreatif di kelas eksperimen lebih baik daripada kelas kontrol. Walaupun nilai rata-rata kelas kontrol lebih kecil dari kelas eksperimen, namun simpangan bakunya lebih kecil. Artinya siswa pada kelas kontrol lebih homogen dari pada kelas eksperimen. Dari data yang telah diperoleh kemudian dianalisis, untuk melihat adanya pengaruh model problem posing terhadap kemampuan berpikir kreatif matematis siswa. Pengaruh aktivitas siswa pada model problem posing terhadap kemampuan berpikir kreatif matematis siswa dapat diketahui dengan melakukan pengujian analisis yaitu uji regresi linier sederhana. Hasil dapat dilihat pada Tabel 4 .

Tabel 4. Hasil Uji Regresi Linier Sederhana

\begin{tabular}{lllllll}
\hline Model & & Sum of Squares & df & Mean Square & F & Sig. \\
\hline 1 & Regression & 2367.220 & 1 & 2367.220 & 9.204 & $.006^{\mathrm{a}}$ \\
& Residual & 6430.114 & 25 & 257.205 & & \\
& Total & 8797.333 & 26 & & & \\
\hline
\end{tabular}

a. Predictors: (Constant), Student_Activity

b. Dependent Variable: CMT_Exp

Tabel 4 menunjukan bahwa nilai Sig. sebesar 0.006, nilai tersebut lebih kecil daripada nilai $\alpha=0.05$. Karena nilai Asymp. Sig (2-tailed) $<\alpha$, maka $\mathrm{H}_{0}$ ditolak dan $\mathrm{H}_{1}$ diterima. Sehingga, dapat disimpulkan bahwa terdapat pengaruh signifikan aktivitas siswa pada pembelajaran matematika menggunakan model problem posing terhadap nilai posttest kemampuan berpikir kreatif matematis siswa.

Tabel 5. Hasil Koefisien Determinasi

\begin{tabular}{lccrr}
\hline Model & $\mathrm{R}$ & R Square & $\begin{array}{c}\text { Adjusted R } \\
\text { Square }\end{array}$ & $\begin{array}{c}\text { Std. Error of the } \\
\text { Estimate }\end{array}$ \\
\hline 1 & $.519^{\mathrm{a}}$ & .269 & .240 & 16.03760 \\
\hline a. Predictors: (Constant), Student_Activity & &
\end{tabular}

Tabel 5 Model Summary, pada bagian ini diperoleh nilai $R=0.519$ dan koefisien determinasi ( $\left.R_{\text {square }}\right)$ sebesar 0,269 . Hal ini menunjukkan pengertian bahwa posttets (Y) dipengaruhi sebesar 26,9\% oleh aktivitas siswa (X), sedangkan sisanya sebesar 73,1\% dipengaruhi oleh sebab-sebab yang lain.

Pendekatan problem posing memberikan seluas-luasnya kesempatan untuk mengajukan masalah sesuai dengan apa yang siswa ketahui sehingga mereka tidak merasa dibatasi dan dapat berkreativitas sesuai dengan materi 
yang sedang diajarkan. Kreativitas akan tumbuh jika adanya keterbukaan terhadap pengalaman dan dapat menilai sesuatu berdasarkan pengalaman diri sendiri dan kemampuannya sendiri untuk bereksperimen terhadap sesuatu yang baru. Siswa yang menggunakan pendekatan problem posing cenderung lebih kreatif dibandingkan siswa yang hanya memiliki pengalaman memecahkan masalah, karena didalam pendekatan problem posing siswa diberikan kesempatan seluas-luasnya untuk mengajukan pertanyaan ataupun masalah mengenai materi. Pada intinya, kreativitas merupakan suatu proses atau hasil dari kemampuan seseorang dalam mengembangkan ide-ide baru untuk memecahkan suatu masalah (Antonio, Lanawati, Wiriana, \& Christina, 2013). Sehingga masalah yang ada tidak sebatas masalah-masalah yang guru berikan dari buku paket maupun buku kumpulan soal-soal. Masalah yang ada bahkan merupakan masalah yang berbeda dan lebih kreatif. Berbeda dengan kemampuan berpikir kreatif matematis siswa di kelas kontrol yang bahkan banyak sekali siswa yang hanya mengajukan masalah hampir sama dengan buku paket maupun soal yang pernah diberikan oleh guru. Hal tersebut mengakibatkan siswa hanya terpaku pada satu masalah saja.

Perolehan data nilai posttest kemampuan berpikir matematis siswa disajikan pada Tabel 6.

Tabel 6. Hasil Kemampuan Berpikir Matematis Siswa

\begin{tabular}{llc}
\hline \multirow{2}{*}{ Data Statistik } & \multicolumn{2}{l}{ Kemampuan Berpikir Matematis } \\
\cline { 2 - 3 } & Eksperimen & Kontrol \\
\hline Jumlah & 27 & 30 \\
Nilai Tertinggi & 97,17 & 58,17 \\
Nilai Terendah & 17,33 & 10,33 \\
Rata-rata & 65,74 & 41,07 \\
Simpangan Baku & 23,68 & 12,57 \\
\hline
\end{tabular}

Tabel 6 menunjukan bahwa nilai rata-rata posttest kemampuan berpikir matematis di kelas eksperimen lebih kecil dari posttest kemampuan berpikir matematis di kelas kontrol. Walaupun nilai rata-rata kelas kontrol lebih kecil dari kelas eksperimen, namun simpangan bakunya lebih kecil. Artinya siswa pada kelas kontrol lebih homogen daripada kelas eksperimen.

Pengaruh aktivitas siswa yang menggunakan pendekatan problem posing terhadap kemampuan berpikir matematis siswa dapat diketahui dengan melakukan pengujian analisis yaitu uji regresi linier sederhana dan determinasi. Hasil dapat dilihat pada Tabel 7. 
Tabel 7. Hasil Uji Regresi Linier Sederhana

\begin{tabular}{lllllll}
\hline Model & & Sum of Squares & df & Mean Square & F & Sig. \\
\hline 1 & Regression & 3279.275 & 1 & 3279.275 & 7.255 & $.012^{\mathrm{a}}$ \\
& Residual & 11299.399 & 25 & 451.976 & & \\
& Total & 14578.674 & 26 & & & \\
\hline
\end{tabular}

a. Predictors: (Constant), Student_Activity

b. Dependent Variable: Math_Ability

Tabel 7 menunjukan bahwa nilai Sig. sebesar 0.012, nilai tersebut lebih kecil daripada nilai $\alpha=0.05$. Karena nilai Asymp. Sig (2-tailed) $<\alpha$, maka $\mathrm{H}_{0}$ ditolak dan $\mathrm{H}_{1}$ diterima. Sehingga, dapat disimpulkan bahwa terdapat pengaruh signifikan aktivitas siswa pada pembelajaran matematika menggunakan model problem posing terhadap nilai posttest kemampuan matematis siswa.

Tabel 8. Hasil Koefisien Determinasi

\begin{tabular}{|c|c|c|c|c|}
\hline Model & $\mathrm{R}$ & R Square & $\begin{array}{l}\text { Adjusted R } \\
\text { Square }\end{array}$ & $\begin{array}{l}\text { Std. Error of the } \\
\text { Estimate }\end{array}$ \\
\hline 1 & $.474^{\mathrm{a}}$ & .225 & .194 & 21.25973 \\
\hline
\end{tabular}

a. Predictors: (Constant), Student_Activity

Tabel 8 menampilkan nilai $R=0.474$ dan koefisien determinasi $\left(R_{\text {square }}\right)$ sebesar 0,225. Hal ini menunjukkan pengertian bahwa posttets (Y) dipengaruhi sebesar $22,5 \%$ oleh aktivitas siswa $(X)$, sedangkan sisanya sebesar 77,5\% dipengaruhi oleh sebab-sebab yang lain.

Hasil analisis menunjukkan terdapat pengaruh model pembelajaran problem posing terhadap kemampuan berpikir matematis siswa diantaranya kemampuan berpikir kreatif dan mengajukan masalah matematis. Pengajuan masalah merupakan salah satu kemampuan untuk mengidentifikasi kreativitas seseorang karena erat hubungannya antara kemampuan berpikir kreatif dengan kemampuan mengajukan masalah.

Kemampuan siswa untuk mengajukan pertanyaan matematika berdasarkan skenario yang diberikan sebagai salah satu tolak ukur kreativitas matematika (Yuan \& Sriraman, 2011). Siswa yang memiliki imajinasi kreatif akan menemukan konsep baru, berawal dari mengajukan pertanyaan, melihat beberapa kemungkinan, dan memandang suatu masalah dari sudut pandang yang berbeda. Oleh karena itu kemampuan mengajukan masalah merupakan aspek penting dalam pengembangan matematika maupun ilmu-ilmu lainnya (Mahmudi, 2007). 


\section{Simpulan}

Berdasarkan hasil peneletian diperoleh kesimpulan terdapat pengaruh aktivitas siswa yang menerapkan pendekatan problem posing terhadap kemampuan berpikir kreatif matematis; tidak terdapat pengaruh aktivitas siswa yang menerapkan pendekatan problem posing terhadap kemampuan mengajukan masalah matematis; dan terdapat pengaruh aktivitas siswa yang menerapkan pendekatan problem posing terhadap kemampuan berpikir matematis. Kemampuan berpikir kreatif matematis dapat ditumbuhkembangkan melalui pembelajaran dengan pendekatan problem posing. Namun, kemampuan mengajukan masalah siswa masih perlu terus dilatih agar siswa lebih percaya diri dan terbiasa dalam mengajukan pertanyaan.

\section{Ucapan Terima Kasih}

Terima kasih pada Lembaga Penelitian Universitas Swadaya Gunung DJati, yang telah memberikan dana hibah dalam penelitian ini.

\section{Daftar Pustaka}

Antonio, T., Lanawati, S., Wiriana, T. A., \& Christina, L. (2014). Correlations Creativity, Intelligence, Personality, and Entrepreneurship Achievement. Procedia-Social and Behavioral Sciences, 115, 251-257.

Anwar, A., \& Sofiyan, S. (2018). Teoritik Tentang Berpikir Reflektif Siswa Dalam Pengajuan Masalah Matematis. Numeracy Journal, 5(1), 91-101.

Ayllón, M. F., Gomez, I. A., \& Ballesta-Claver, J. (2016). Mathematical Thinking and Creativity through Mathematical Problem Posing and Solving. Journal of Educational Psychology-Propósitos y Representaciones, 4(1), 195-218.

Hartati, L. 2016. Penerapan Model Pembelajaran Kooperatif Terhadap Hasil Belajar Matematika Ditinjau Dari Kreativitas Belajar. Prosiding Seminar Nasional Matematika dan Pendidikan Matematika: Uiversitas Negeri Yogyakarta.

Hendriana, H., Rohaeti, E. E., \& Sumarmo, U. (2017). Hard Skills Dan Soft Skills Matematik Siswa. Bandung: Refika Aditama.

Hendriana, H., \& Fadhillah, F. M. (2019). The Students'mathematical Creative Thinking Ability of Junior High School through Problem-Solving Approach. Infinity Journal, 8(1), 11-20.

Herawati, O. D. P., Siroj, R. A., \& Basir, M. D. (2010). Pengaruh Pembelajaran Problem Posing Terhadap Kemampuan Pemahaman Konsep Matematika Siswa Kelas XI IPA SMA Negeri 6 Palembang. Jurnal Pendidikan Matematika, 4(1), 70-80.

Herianingtyas, N. L. R., \& Harmawati, R. E. (2017). Optimalisasi Kemampuan Berpikir Kreatif dalam Pembelajaran Sains Melalui Discovery Learning Berwawasan Lingkungan. Prosiding SNPBS (Seminar Nasional Pendidikan Biologi dan Saintek) Ke-2, 547-556.

Johnson, D. (2010). Teaching With Authors' Blogs: Connections, Collaboration, Creativity. Journal of Adolescent \& Adult Literacy, 54(3), 172-180. 
Knott, L. (2010). Problem posing from the foundations of mathematics. The Mathematics Enthusiast, 7(2), 413-432

Mahmudi, A. (2007). Meningkatkan Kreativitas Siswa Melalui Problem Posing. Pythagoras: Jurnal Pendidikan Matematika, 3(1), 43-50.

Mahmuzah, R. (2015). Peningkatan Kemampuan Berpikir Kritis Matematis Siswa SMP Melalui Pendekatan Problem Posing. Jurnal Peluang, 4(1), 64-72.

Mann, E. L. (2005). Mathematical Creativity and School Mathematics: Indicators of Mathematical Creativity in Middle School Students. University of Connecticut.

Royani, M., \& Muslim, B. (2014). Keterampilan Bertanya Siswa SMP Melalui Strategi Pembelajaran Aktif Tipe Team Quiz pada Materi Segi Empat. EDU-MAT, 2(1), 22-28.

Saragih, S. (2011). Meningkatkan Kemampuan Keruangan melalui Pembelajaran Matematika Realistik dan Kelompok Kecil Siswa SMP. Jurnal Pendidikan Matematika, 2(2), 118-129.

Silver, E. A. (1994). On Mathematical Problem Posing. For The Learning of Mathematics, 14(1), 19-28.

Siswono, T. Y. E. (2010). Leveling Students'creative Thinking In Solving and Posing Mathematical Problem. Journal on Mathematics Education, 1(1), 17-40.

Sternberg, R. J. (2006). The Nature of Creativity. Creativity research journal, 18(1), 87-98.

Stoyanova, E., \& Ellerton, N. F. (1996). A Framework for Research Into Students' Problem Posing in School Mathematics. Technology in Mathematics Education, 1(1), 518-525.

Torrance, E. P. (1972). Can We Teach Children to Thinking Creativily?. The Journal of Creative Behaviour, 6(2), $114-143$.

Ulfah, U., Prabawanto, S., \& Jupri, A. (2017). Students' Mathematical Creative Thinking through Problem Posing Learning. Journal of Physics: Conference Series, 895(1), 012097.

Wasiran, Y., \& Andinasari, A. (2019). Meningkatkan Kemampuan Berpikir Kreatif dan Penalaran Adaptif Matematika Melalui Paket Instruksional Berbasis Creative Problem Solving. JNPM (Jurnal Nasional Pendidikan Matematika), 3(1), 51-65.

Yuan, X. (2009). An Exploratory Study of High School Students' Creativity and Mathematical Problem Posing in China and The United States. Illinois State University.

Yuan, X., \& Sriraman, B. (2011). An Exploratory Study of Relationships Between Students' Creativity and Mathematical Problem-Posing Abilities: Comparing Chinese and US Students. The Elements of Creativity and Giftedness in Mathematics, 1(1), 5-28. 